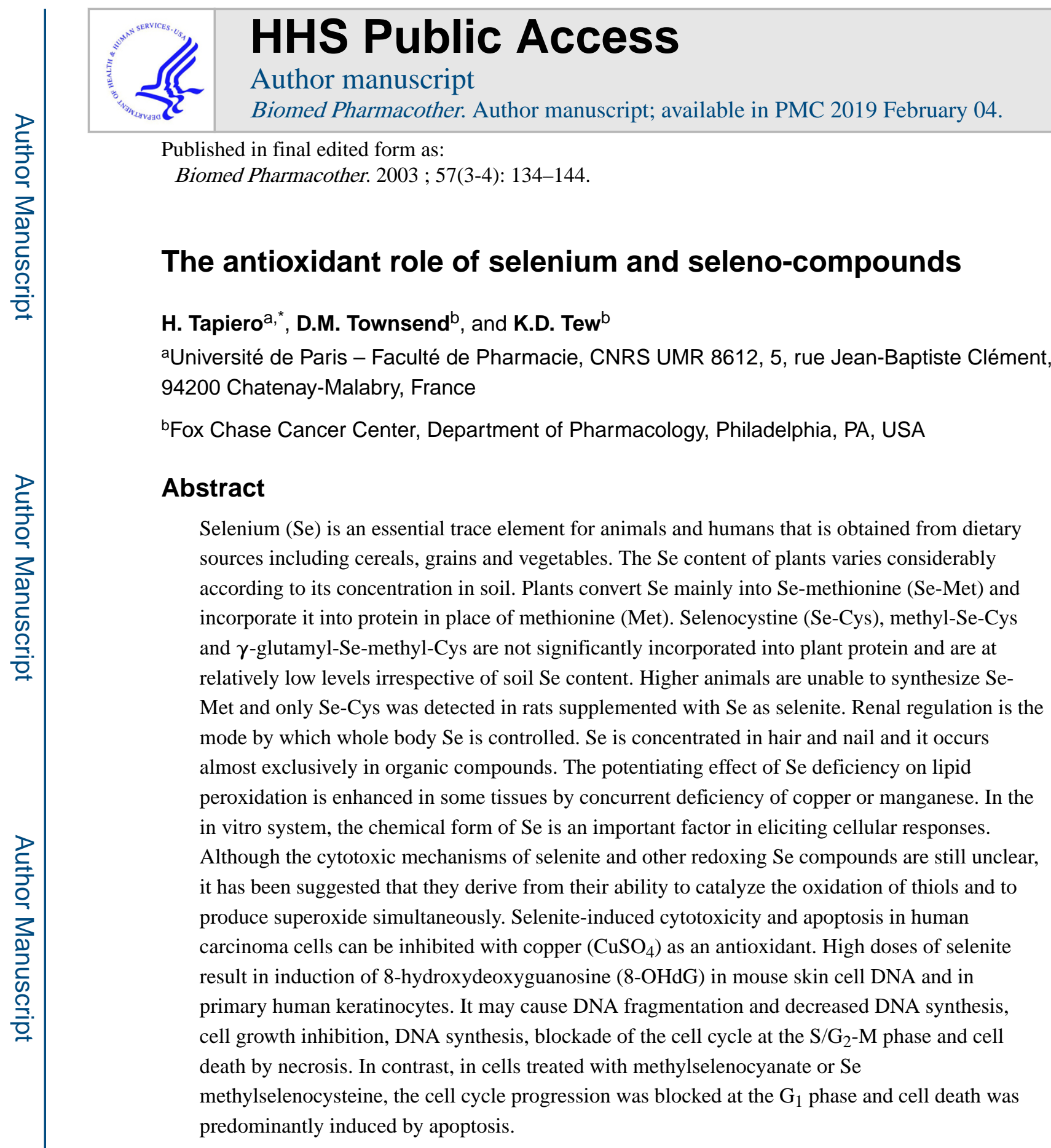

\title{
Keywords
}

Selenium; Selenoproteins; Glutathione peroxidase; Thioredoxin system

\section{Bioavailability and distribution}

The selenium (Se) content of plants varies tremendously according to its concentration in soil which varies regionally. Volcanic soils are particularly susceptible to mineral leaching. Around the world, there are the regions that are so Se poor that overt deficiency syndromes

'Corresponding author. haimtapiero@aol.com (H. Tapiero). 
are endemic: these regions include arid regions of Australia, northeast China, northern North Korea, south central China, Nepal and Tibet. Central Africa, particularly the Democratic Republic of Congo has similar overlapping deficiencies when the diet is derived almost entirely from local foods, with little or no importation of foods from outside areas. Plants convert Se mainly into Se-methionine (Se-Met) and incorporate it into protein in place of methionine (Met). Se-Met can account for $>50 \%$ of the total Se content of the plant whereas, selenocystine (Se-Cys), methyl-Se-Cys and $\gamma$-glutamyl-Se-methyl-Cys are not significantly incorporated into plant protein and are at relatively low levels irrespective of soil Se content. In the presence of Se, Saccharomycetes cerevisae may assimilate up to $3 \mathrm{mg} / \mathrm{g}$, and most of the total $\mathrm{Se}(>90 \%)$ is in the form of L-Se-Met. Higher animals are unable to synthesize SeMet and only Se-Cys was detected in rats supplemented with Se as selenite (Fig. 1). In mammals, ingested Se-Met is absorbed in the small intestine via the $\mathrm{Na}^{+}$-dependent neutral amino acid transport system [1].

Bioavailability is defined as the proportion of an ingested nutrient that is used for normal physiological functions or storage. Bioavailability is influenced by endogenous factors, including growth, pregnancy or lactation, the efficiency of digestion, gut transit time and the presence of gastrointestinal disorders or disease. Although the proportion of the nutrient absorbed from the gastrointestinal tract is a major determinant (for calcium and zinc), tissue utilization of the absorbed nutrient and renal conservation (Se) are also important factors influencing bioavailability [2]. Se bioavailability depends on the conversion of absorbed Se into a biologically active form and tissue retention. However, because tRNA ${ }^{\text {Met }}$ does not discriminate between Met and Se-Met, a greater percentage of Se-Met is incorporated nonspecifically into body proteins in place of Met in low Met diet [3]. As determined by GSHPx activity in platelets, Se-Met is absorbed and retained more efficiently than inorganic selenate or sodium selenite $\left(\mathrm{Na}_{2} \mathrm{SeO}_{3}\right)$ [4]. Renal regulation is the mode by which whole body Se is controlled. Thus, pregnant women meet their Se needs by decreasing urinary losses, and it has been shown that they excreted less urinary Se than did non-pregnant women [5]. During lactation, Se was also detected in human milk and more Se was detected in milk of mothers consuming Se-Met than selenite [6,7].

An adequate Se intake has been estimated at $50 \mu \mathrm{g} / \mathrm{d}$ with toxic levels being estimated to occur with intakes of the order of 350-700 $\mu \mathrm{g} / \mathrm{d}$. However, chronic feeding of inorganic $\mathrm{Se}$ compounds ( $>5 \mathrm{ppm})$ can be hepatotoxic and teratogenic in animals and humans.

Intake of dietary Se-Met is reflected in the Se-content of human skeletal muscle which may vary according to the population; the highest in Japanese adults $(1700 \mathrm{ng} / \mathrm{g})$ and the lowest in New Zealand adults $(61 \mathrm{ng} / \mathrm{g}$ ) and in the populations of Se poor regions. In plasma, Se is mainly found in the albumin fraction and in erythrocytes, mainly incorporated into hemoglobin [8]. Se in the form of Se-Met is also significantly retained in proteins in the brain [9].

\section{Pathologies associated with Se deficiency}

Se deficiency affects glutathione (GSH) metabolism by increasing its synthesis and release in the liver with concomitant increase in plasma GSH [10]. Increased plasma GSH can lead 
to a depletion of cysteine and impairment of protein synthesis. Se deficiency is also accompanied by a decrease in glutathione peroxidase (GSH-Px) activity and results in an increase in hepatic glutathione-S-transferase (GST) activity [11] Recently, it has been reported that Se deficiency decreases the plasma concentrations of cysteine, cystathionine and homocysteine [12]. Since plasma homocysteine is measured as a risk factor for cardiovascular disease and as a clinical marker for deficiencies of folate [13-16], the effects of dietary Se on redox status of homocysteine suggest that Se deficiency can affect the metabolism of Met [17]. The biochemical mechanism by which Se deficiency can contribute to the development of atherosclerotic cardiovascular disease is by increased thromboxane B2 (leading to platelet aggregation), and decreased prostacyclin (which prevents aggregation). Se deficiency may also have a role in immune dysfunction and has been associated with impaired defense against enterovirus infection [18]. Se deficiency is also associated with a decrease in some of the isoenzymes of cytochrome P-450. In contrast, it is associated with an increase in uridine diphosphate (UDP) glucuronyl transferase activity. Se deficiency affects the ability of an individual to metabolize drugs and may be associated with increased toxicity of some drugs and decreased efficiency of others [19] (Table 1 ).

\subsection{Keshan disease}

Keshan disease occurs in areas where concentrations of iodine and Se in the soil, food supply and human plasma are all low [20-23]. The average intake of Se in Keshan disease endemic areas has been estimated at $10 \mu \mathrm{g} / \mathrm{d}$. The disease is an endemic cardiomyopathy appearing in women of childbearing age and preschool children. Keshan disease occurs with symptoms of congestive heart failure or less frequently, as sudden death or stroke from diffuse cardiac thrombosis. Autopsy reveals cellular edema, mitochondrial swelling and overlapping striations of fibrotic tissue, indicating multiple bouts of localized necrosis [24,25]. A myocarditic Coxsackie virus has been associated with the pathogenesis of Keshan disease.

\subsection{Kashin-Beck disease}

Kashin-Beck disease is an osteoarthropathy that is endemic and limited to areas of combined mineral deficiency of both iodine and Se. Affected Kashin-Beck patients have much lower serum thyroxine and triiodothyronine and higher rates of goitre than nonKashin-Beck patients $[21,22,26]$. Elevated thyrotropin (TSH) and lower urinary iodine are predictors of disease occurrence [16]. Urinary iodine-selenium in Kashin-Beck patients is $1.2 \mu \mathrm{g} / \mathrm{dl}$ compared to $1.8 \mu \mathrm{g} / \mathrm{dl}$ in neighboring disease-free areas. Both serum Se concentrations and the activity of serum GSH-Px are lower in residents of villages where the disease is endemic. Average serum Se concentrations among residents of the Kashin-Beck endemic areas averages less than $11 \mathrm{ng} / \mathrm{ml}$ while among areas without mineral deficiency, concentrations are $60-105 \mathrm{ng} / \mathrm{ml}$ are reported [27]. The disease is characterized by a range of bone and joint malformations that appear during childhood or puberty and progress until growth ceases. Histological observations indicate that the disease-associated joint malformations result from necrosis of chondrocytes during bone growth and from the secondary repair and remodeling that follows clearance of necrotic tissue by the circulatory system [28]. However, Se deficiency alone does not induce joint malformations in animal models and it has been reported that joint morphology in rats is similar to that found if the 
disease is induced in conjunction with fulvic acid contaminants found in water sources [29].

Fulvic acid is the water soluble fraction of the products of microbial and chemical degradation of plant and animal matter. It is present in higher concentrations in well water of Kashin-Beck endemic communities than in disease-free areas. Fulvic acids are a heterogeneous group of complex polymers with highly oxygen-substituted benzene rings localized to bone and cartilage tissue with low Se concentrations. The highly reactive functional groups including carboxyls, hydroxyls, carbonyls, phenols and quinones contribute to a high concentration of stable free radicals [30].

\section{The selenoproteins}

All mammalian selenoproteins contain Se in the form of the amino acid selenocysteine (Sec) which is encoded by the UGA triplet. There are two forms of tRNA ${ }^{[\mathrm{Ser}] \mathrm{Sec}}$, which are essential for the synthesis of all selenoproteins. The tRNA ${ }^{[\mathrm{S}-\mathrm{er}] \mathrm{Sec}}$ isoforms are both the site of Sec synthesis and the adaptor molecules which recognize the appropriate UGA codons in selenoprotein mRNAs. Twenty-two known eukaryotic selenoproteins are organized into distinct selenoprotein groups on the basis of the location and functional properties of Sec. GSH-Px, selenoprotein P, type I iodothyronine 5'-deiodinase (DI-I) and thioredoxin reductase (TR) have been characterized in animals [31,32] and human [33]. Ap-proximately, half of the characterized selenoproteins have been implicated to have antioxidant functions [34]. Thus, increased risks of human diseases associated with Se deficiency may be attributable to increased oxidative stress and alterations in redox signaling. Selenoproteins may be subdivided into groups based on the location of Sec in selenoprotein polypeptides. Group I (GPx group) is the most abundant and includes proteins in which Sec is located in the N-terminal portion of a relatively short functional domain; 80-250 amino acid residues. Secondary structure reveals the presence of both alpha-helices and beta-sheets in proteins. In the proteins of the GPx group, Sec is either oxidized during catalysis to selenenic acid or forms selenosulfide bonds. The second group (TR group) is characterized by the presence of $\mathrm{Sec}$ in C-terminal sequences. It includes three mammalian TRs and Drosophila G-rich protein. Another group consists of three deiodinase isozymes, Se-R, Se-N, SPS2 and the 15 $\mathrm{kDa}$ selenoprotein.

\subsection{The glutathione peroxidase (GSH-Px) group}

The GPx group includes GPx isozymes, Se-W, Se-P, Se-Pb, Se-T, Se-T2, and Drosophila $\mathrm{BthD}$. The mammalian GPx isozymes catalyze GSH-dependent degradation of various hydroperoxides [35]. Support for the protective role of Se came through the discovery of GSH-Px in the cytosol. The major physiologic role of GSH-Px is to maintain appropriately low levels of hydrogen peroxides within the cell, thus decreasing potential free radical damage. It provides a second line of defense against hydroperoxides which can damage membranes and other cell structures [36]. Se is an essential component of GSH-Px that acts synergistically with tocopherol in the regulation of lipid peroxidation. In tandem with catalase, it degrades hydrogen peroxide to water via glutathione reductase and flavin adenine dehydrogenase (FAD) in the pentose phosphate shunt (Fig. 2). At present, there are four known members of the family of GSH-Px. GSH-Px ${ }_{1}$ is the most abundant selenoprotein in mammals. The activity of GSH-Px ${ }_{1}$ is regulated in the liver by Se status. GSH-Px $x_{1}$ is a 
cytosolic enzyme expressed in every cell type and is thought to be one of the major antioxidant proteins in mammals. GSH-Px 2 is the closest homolog of GSH-Px 1 , but it is found predominantly in the gastrointestinal tract [37]. GSH-Px 3 is the second most abundant selenoprotein in plasma after Se-P and is immunochemically distinct from $\mathrm{GSH}_{-} \mathrm{Px}_{1}$ [38]. It is a secreted glycoprotein and like GSH-Px $x_{1}$ and GSH-Px $2, \mathrm{GSH}^{-\mathrm{Px}_{3}}$ is homotetrameric composed of $\sim 22 \mathrm{kDa}$ polypeptides. GSH-Px 4 is also called phospholipid hydroperoxide glutathione peroxidase (PHGPx) since it reduces specifically fatty acid hydroperoxides esterified to phospholipids [39]. In contrast to other isoforms, it is a $\sim 20 \mathrm{kDa}$ monomer polypeptide, localized to both cytosol and mitochondria. GSH-Px 4 and GSH-Px $x_{1}$ have been shown to be differentially regulated by Se status [40].

\subsection{Selenoprotein $\mathbf{P}$}

Selenoprotein $\mathrm{P}(\mathrm{Se}-\mathrm{P})$ is the major plasma selenoprotein. Its peptide concentration in rat plasma is $30 \mu \mathrm{g} / \mathrm{ml}$ which is over $60 \%$ of the Se in rat plasma [41]. In human plasma, the peptide concentration is much lower, $5 \mu \mathrm{g} / \mathrm{ml}[42,43]$. The half life of Se-P is relatively short; $3-4 \mathrm{~h}$ as compared to $12 \mathrm{~h}$ for GSH-Px 3 [44]. Se-P binds to cells and appears to be expressed in various tissues such as arterial endothelial cells and hepatic sinusoidal endothelial cells. Se-P is a heparin binding protein and it seems likely that its association with cells is through binding to heparan sulfate proteoglycans. Binding of proteins to heparin is mediated by positively charged amino acids, usually lysine and arginine. Histidine can also participate in heparin binding, if it is positively charged. Se-P-mRNA has been detected in human liver, kidney and intestine $[45,46]$. In cultured cells, it was shown that astrocytes, myocytes, hepatocytes and Leydig cells from the testis express the Se-P $[47,48]$. However, ${ }^{* *}$ Se-P mRNA has been shown to be lower in colorectal adenomas than in normal colon mucosa and it was undetectable in a rat renal cell carcinoma model $[49,50]$. Se-P is the only characterized mammalian selenoprotein that contains multiple Se-Cys residues $[51,52]$ and its level is less affected by Se status than other selenoproteins such as GSH-Px 1 [53]. Digestion of Se-P with glycosidases indicated that it contains carbohydrates [41]. A new selenoprotein was isolated from a human lung adenocarcinoma cell line. The protein, a homodimer of 57-kDa subunits was shown to contain Se in the form of Se-Cys. However, it was distinguished from Se-P by the absence of glycosyl groups on the protein [33]. Se-P has been proposed to serve in oxidant defense in the extracellular space and also to transport Se from the liver to other tissues [54]. Patients with cirrhosis have depressed Se-P levels that correlate with the severity of their illness [55]. Impairment of Se-P synthesis by the diseased liver is the cause for the low plasma Se-P concentration.

\subsection{SelenoproteinW and $\mathbf{R}$}

Selenoprotein $\mathrm{W}$ (Se-W) is a low molecular weight selenoprotein (87 amino acid protein) containing one Se-Cys residue and exists in four forms. One isoform has GSH bound to a specific cysteine residue indicating that $\mathrm{Se}-\mathrm{W}$ may have redox functions. Low levels of Se$\mathrm{W}$ were ubiquitously expressed in primates and humans. However, Se-W was highestin skeletal, cardiac muscle and brain [56]. In contrast, Se-W was notubiquitously expressed in rodents. Rats fed with Se accumulated Se-W in skeletal muscle and brain and to a lower extent in spleen and testis but not in liver, kidney, intestinal mucosa, lungs, plasma or erythrocytes [57]. Dietary Se deficiency causes white muscle disease which results in 
calcification of skeletal and cardiac muscle in primates and sheep, while in humans, it is associated with Keshan disease cardiomyopathy. In contrast, rodent cardiac muscle is not affected by Se depletion [57,58]. Se depletion reduces the half life of Se-W mRNA [59]. Se$\mathrm{R}$ contains Se-Cys in the C-terminal portion [60]. It has no homology to known proteins and its function is still not known.

\subsection{The thioredoxin group}

The thioredoxin (Trx) system comprises NADPH, Trx and TR. Trx is a small ubiquitous dithiol protein containing 104 amino acids with one S-S bridge, two SH groups and conserved active site (Trp-Cys-Gly-Pro-Cys). Trx is a widely distributed redox protein that regulates several intra-cellular redox-dependent processes and stimulates the proliferation of both normal and tumor cells (Fig. 3). Trx regulates enzymes and transcription factors by thiol redox control and is a hydrogen donor for ribonucleotide reductase, a protein involved in repair mechanisms essential for DNA synthesis and a general protein disulfide reductase involved in redox regulation (reduced Trx is $10^{4}-10^{6}$ more efficient than DTT).

Selenite, selenoglutathione (GS-Se-GS) and Se-Cys are efficiently reduced by Trx and also directly by NADPH and mammalian TR (but not by the E. coli enzyme) [61]. Trx undergoes spontaneous oxidation thereby losing its ability to stimulate cell growth but maintaining its substrate activity for NADPH-dependent reduction by human TR. In addition, Trx undergoes also a slower spontaneous conversion to a homodimer that does not stimulate cell proliferation and is not a substrate for reduction by TR. Both conversions can be induced by chemical oxidants and are reversible by treatment with the thiol reducing agent dithiothreitol [62]. Reduction of disulfides inactivates extracellular proteins such as coagulation factors, insulin or PDGF. Trx can act as a growth factor for macrophages or act as a mediator of cell growth inhibition by $\gamma$-interferon. Trx is expressed by most cells of the human body and can also be released by cells such as lymphocytes upon activation or oxidative stress, exerting a cocytokine and cytoprotective activity [63]. Trx is overexpressed and secreted in certain tumor cells and its expression is decreased during dexamethazone, staurosporine, etoposide and thapsigargin-induced apoptosis but not by $N$-acetyl-sphingosine [64]. Thus, increased Trx in human cancer cells may result in an increased tumor growth through inhibition of spontaneous apoptosis and a decrease in the sensitivity of the tumor to drug-induced apoptosis.

Mammalian TR, like lipoamide dehydrogenase and glutathione reductase, is a member of the pyridine-nucleotide-disulfide oxidoreductase family of dimeric flavoenzymes [65]. These proteins are homodimeric selenocysteine (Se-Cys)-containing proteins composed of two subunits of 116,000 molecular weight that catalyze the NADPH-dependent reduction. In TRs, Se-Cys is located in the C-terminal redox motif (Gly-Cys-Se-Cys-Gly) which is essential for enzyme activity. By reducing Trx that is overex-pressed in a number of human tumors, TR may play a role in regulating the growth of normal and cancer cells. Se deficiency leads to a decrease in TR activity from control to $4.5 \%$ in liver and $11 \%$ in kidney whereas brain TR activity was not affected by Se deficiency [66]. Gold inhibited TR activity in the liver in a manner typical of its effect on selenoenzymes. The Se effect on TR activity varies according to the cell type. In the presence of $1 \mu \mathrm{M}$ Se in the form of sodium selenite, 
TR activity increased by 37 -fold in MCF-7 breast cancer cells, 19 -fold in HT-29 colon cancer cells and eightfold in A549 lung cancer cells. In contrast, no increase could be detected in Jurkat or HL-60 leukemia cells. Under the same conditions, TR mRNA levels increased by 2.5 -fold and TR stability was enhanced significantly (the half life for degradation was $21 \mathrm{~h}$ compared to $10 \mathrm{~h}$ in the absence of Se). In contrast, Trx mRNA, protein levels and Trx mRNA stability were not affected by Se. Thus, the effect of Se on TR activity is specific and likely due to increased incorporation of Se into the enzyme $[67,68]$. $\mathrm{TR}_{1}$, a cytosolic enzyme, is the most abundant TR isozyme in mammalian cells [69]. $\mathrm{TR}_{2}$ was characterized as a fusion of the $\mathrm{C}$-terminal TR domain and the $\mathrm{N}$-terminal glutaredoxin domain that allows $\mathrm{TR}_{2}$ to ac-quire GSH reduction function while maintaining specificity for $\operatorname{Trx}$ reduction. $\mathrm{TR}_{2}$ expression was specific to testes and is puberty-dependent. $\mathrm{TR}_{3}$ is a mitochondrial enzyme but can also be targeted to other cellular compartments [70].

\subsection{Type I iodothyronine 5'-deiodinase (DI-I)}

The thyroid gland synthesizes two major hormones triiodothyronine $\left(\mathrm{T}_{3}\right)$, the main biologically active thyroid hormone which occurs in liver, kidney and thyroid and thyroxine $\left(\mathrm{T}_{4}\right)$ which is produced solely by the thyroid and is biologically inactive [26] (Fig. 4). The control of thyroid hormone $\left(\mathrm{T}_{3}\right)$ is via DI-I, a selenoenzyme which produces most of the circulating $\mathrm{T}_{3}$ by deiodination of $\mathrm{T}_{4}$ in peripheral tissues [26]. Deiodination of $\mathrm{T}_{4}$ is also catalyzed by type II 5 -deiodinase (DI-II) which produces $\mathrm{T}_{3}$ primarily for local use and occurs in the central nervous system, and pituitary gland [71]. Thyroid hormone (TH) production is controlled by thyroid stimulating hormone (TSH), secreted by the pituitary gland in response to its circulating levels and in response to iodine availability [72]. However, irreversible dam-age of the thyroid gland caused by iodine supplementation to animals deficient in both iodine and Se suggested that it resulted from an impaired Sedependent antioxidant system such as the GSH-Px system $[73,74]$.

\section{The protective effect of Se compounds}

\subsection{Se in cancer prevention}

A confluence of evidences show an association between Se and the processes which lead to, or prevent, cancers [75-79]. In animal models, supplementation of inorganic Se in the diet protects against cancer induced by a variety of chemical carcinogens [80]. Se compounds like selenite and selenate have strong inhibitory effects particularly on mammalian tumor cell growth. The mechanism of action of selenite and selenate appears to be distinct. Cells treated with selenite accumulated in the S-phase and selenite-mediated growth inhibition was irreversible whereas selenate treatment lead to an accumulation of cells in $\mathrm{G}_{2}$ and the effect on cell growth can be reversed [81].

Prospective cohort studies in several countries have independently shown that cancer patients have a significantly lower mean prediagnostic serum Se level than controls [82-86] and negative associations for various parameters of Se status and risks to cancers or precancerous lesions of the bladder [82], brain [87], esophagus [88], lung [89], head and neck [90], ovary [91], pancreas [92], thyroid [93], stomach [94-96], melanoma [97], prostate [98] and colon [99]. The possibility that Se deficiency may increase cancer risk might be 
predicted on the basis of limited expression of selenoenzymes involved in antioxidant protection (glutathione peroxidases) and redox regulation (TRs). The induction of skin tumors by either ultraviolet irradiation [100-102] or phorbol esters [103] varied inversely with skin GPx activity in animals. The protective effect of $\mathrm{Se}$ in the form of sodium selenite or Se-Met is dose dependent but not organ specific. Se-Met has radioprotective properties [104] and protects against UV-light-induced skin damage in mice [100]. Se-Met can inhibit both the initiation and post-initiation phases of chemically induced mammary carcinogenesis.

Se intake may be related to differences in cancer incidences in various populations [84,105]. Several case control studies confirmed that people with low blood Se had an increased risk of cancer [99] and those supplemented with selenized brewer's yeast decreased the overall cancer morbidity and mortality rate by nearly $50 \%$ [106]. Se concentrations in foods vary considerably even among different brand names of the same food product (reflecting different geographical origins) and the chemical form of Se is also variable [107,108]. There is evidence of anticarcinogenic activities for several intermediary metabolites of Se (Fig. 5a). Selenodiglutathione (GS-Se-SG) unstable under physiological conditions is unlikely to accumulate in cells and breaks down to glutathione selenol (GSSeH) and hydrogen selenide $\left(\mathrm{H}_{2} \mathrm{Se}\right)$. GS-Se-SG has been shown to block protein synthesis by inhibiting eukaryotic initiation factor 2 to suppress the mRNAs for several GPx isoforms [109] and to serve as an oxidant of Trx [110]. In addition, GS-Se-SG has been shown to inhibit DNA-binding of the transcription factor AP-1 [61], ribonucleotide reductase [81], cell proliferation and enhance apoptosis [111]. Apoptosis stimulation appears to be related to the production of superoxide anion $\left(\mathrm{O}_{2}^{-}\right)$and $\mathrm{H}_{2} \mathrm{O}_{2}$ as a consequence of $\mathrm{H}_{2}$ Se oxidative metabolism.

While Se-Met is excellent for increasing the Se concentrations in tissues, it is relatively ineffective for suppression of carcinogenesis [75,112]. Although the mechanism for Se inhibition of carcinogenesis is still unclear, it might be associated with the monomethylated form of Se that can be metabolized to methylselenol which may provide better cancer protection [113]. With a high intake of selenite or Se-Met, the levels of methylated metabolites (methylselenol, dimethyl selenide and trimethylselenonium) were increased [114]. Methylated Se compounds have been shown to modify various biological processes including suppression of angiogenesis [115] and cancer prevention [116]. Se ingested as SeMet may follow the transsulfuration pathway, converted to Se-Cys and then cleaved to produce selenide. In contrast, Se-methyl selenocysteine (SeMSC) which is prevalent in broccoli [117] may be converted to methyl selenol by cleavage of the Se-methyl group (Fig. $5 b)$. The chemical form of Se found in broccoli is similar to that found in garlic [117,118]. Hence, the reduced risk of cancer seems to be a consequence of the uniqueness of Se in those plants and not a consequence of the total intake of Se, garlic or broccoli. Thus, $\mathrm{Se}$ from Se enriched broccoli is more effective than inorganic forms of Se against chemically induced colonic aberrant crypt formation and mammary cancer development [112]. Seenriched broccoli is shown to be protective against intestinal cancer susceptibility in multiple intestinal neoplasia (Min) mice [119] and in chemically induced mammary and colon cancer in rats $[75,120]$. Thus, monomethyl selenol is considered to be the critical metabolite for protection against certain cancers [75]. Moreover, it has been reported that 
SeMSC did not affect the growth of normal untransformed cells in the mammary gland and the effect was manifested only in premalignant lesions [121].

Synthetic organoselenium compounds have been designed to achieve greater chemoprevention efficacy and to reduce toxic side effects (Fig. 6) [122]. Administration of synthetic organo-Se to DMBA-induced mammary female rats tumors showed that it acted in both initiation and progression phases. During the initiation phase, the 1,4 phenylenebis(methylene)selenocyanate (p-XSC) inhibited total DMBA-DNA binding in the mammary gland $[123,124]$. The chemopreventive activity of p-XSC during the postinitiation stage of carcinogenesis has been suggested following inhibition of prostaglandin $\mathrm{E}_{2}\left(\mathrm{PGE}_{2}\right)$ levels and enhancement of GSH-Px activity in the rat colon. In a lung mouse tumor induced by a nicotine derived nitrosamine, NNK (4-methyl-nitrosamino)-1-(3pyridyl)-1-butanone), $\mathrm{p}$-XSC significantly decreased lung tumor multiplicity in a dosedependent manner. Treatment with $\mathrm{p}$-XSC caused a three to sixfold greater accumulation of Se within cells than did treatment with equivalent amounts of inorganic Se and produced a dose-dependent reduction in cell number and a dose-dependent increase in cell death by apoptosis $[125,135]$. The p-XSC chemopreventive activity may be explained at least in part by the inhibition of DNA adduct formation. While p-XSC inhibited the formation of $O^{6}$ methylguanine and 7-methylguanine in the lung, sodium selenite at $5 \mathrm{ppm}$ had no effect on DNA adduct formation and had no protective effect against lung tumor induction. In addition, p-XSC was markedly less toxic and at level of $80 \mathrm{mg} / \mathrm{kg}$ (equivalent to $40 \mathrm{mg} / \mathrm{kg}$ Se) was shown to inhibit DMBA-induced mammary carcinogenesis in the initiation stage by suppressing the formation of DMBA-DNA adducts [123,126]. p-XSC also inhibited mammary and colon carcinogenesis in the postinitiation or tumor promotion phase [118].

\subsection{The role of Se in HIV/AIDS}

Chronic oxidative stress has been reported during the early and advanced stages of HIV-1 infection [127]. Oxidative stress has been linked to HIV-induced apoptosis of T lymphocytes [128], to alterations in the HIV promoter that may produce progression to AIDS in patients with latent HIV [129] and to the development of AIDS Kaposi sarcoma [130]. It has also been identified as one of the factors that may lead to neural damage [131]. In addition, oxidative stress may induce alterations in the interleukin profile, contributing to immune dysregulation and increased viral replication during the progression of HIV-1 infection to AIDS [132]. Moreover, changes in levels of ascorbic acid, tocopherols, carotenoids, Se and GSH have been observed in plasma and in various tissues [127,133]. Biochemical deficiency of vitamins A, B6, B12 and zinc levels has been associated with an increased rate of disease progression while normalization of these levels has been linked to slower disease progression [134,135]. Se among other micronutrients has been demonstrated to affect the immune process and may act at different levels. In animal models, Se deficiency impairs the ability of phagocytic neutrophils and macrophages to destroy antigens. In HIV-infected patients, Se deficiency has been significantly correlated with total lymphocyte counts. Plasma Se levels have been positively correlated with CD4 cell counts and CD4/CD8 ratio [136]. It has been suggested that the increased oxidative stress in HIV infection is caused by elevated IL-8 levels which exhausts the available Se to protect cells against the inflammatory response [137]. In vitro models have shown that Se enhances interleukin-2 production in a 
dose-dependent manner (the cytokine responsible for the earliest and most rapid expansion of T lymphocytes). This probably occurs via the increased expression of high-affinity receptors [138]. In addition, Se reduces TNF receptors and prevents the adverse effects of high circulating TNF levels including Kaposi's sarcoma. It seems also to suppress TNFinduced HIV replication probably through selenoprotein synthesis particularly in the GSH and Trx systems $[136,139,140]$. Thus, maintaining an optimal Se status in HIV-1 infected men and women may help to increase the enzymatic defense and improve general health in those patients [141,142].

\subsection{Se and aging}

In humans, some controversy exists concerning the effects of Se levels on aging. Circulating Se concentrations either fall slightly or remain stable with age. However, the tissue distribution may be altered. Se in hair has been found to decline from a mean of $0.76 \mu \mathrm{g} / \mathrm{g}$ of hair in $11-15$ years old to a mean of 0.55 between 61 and 70 years old [20]. Moreover, several studies have shown that aging cells accumulate oxidative damage [143]. The aging lymphocyte population fails to expand and damage to both mitochondrial and nuclear DNA occurs. Lipid peroxidation and accumulation of carbonyl moieties on protein are produced by oxidative stress. Mitochondria accumulate age-related damage, releasing more reactive oxygen species. Thus, GPx and other selenoproteins may play a role in slowing cellular damage and the aging process. Moreover, the efficiency of the immune system declines with age. The decline in the effectiveness of the immune system associated with aging increases the chances of neoplasia. The response to antigen challenge decreases along with a decrease in the ratio of CD4 to CD8 T cells and of $\mathrm{CD}^{-}$to $\mathrm{CD}^{+} \mathrm{B}$ cells $[144,145]$. Aged mice produced weak interferon gamma and interleukin-2 responses to Trypanosoma musculi [146]. In humans, low Se status in the elderly was correlated with lower triiodothyrinine to thyroxine ratios due to the raised thyroxine concentrations. Se supplementation decreased the serum thyroxine concentration [147]. A deficiency in thyroxine to triiodothyrinine conversion will affect general metabolism including immunity [148-151]. Finally, telomere length decreases with age in peripheral leukocytes and is accelerated by oxidative stress in fibroblasts. The rate of telomere shortening and carbonyl group accumulation was inversely correlated with GPx activity in fibroblasts [152].

In conclusion, Se is a nutritional trace element that is incorporated into selenoproteins as the amino acid selenocysteine and it is known to be both radioprotective and protect against UVlight-induced skin damage in mice. It may inhibit the initiation and post-initiation phases of chemically induced mammary carcinogenesis and the expression of some viruses and is important for optimal functioning of the immune system. Se supplementation also increases the activities of the selenoproteins, GSH-Px and TR which serve as cellular antioxidants. It is therefore suggested that Se supplementation through reinforcement of endogenous antioxidative systems may be beneficial as an adjuvant therapy for some human pathologies.

\section{References}

[1]. Vendeland SC, Deagen JT, Butler JA, Whanger PD. Uptake of selenite, selenomethionine and selenate by brush border membrane vesicles isolated from rat small intestine. Biometals 1994;7:305-12. [PubMed: 7812115]

Biomed Pharmacother. Author manuscript; available in PMC 2019 February 04. 
[2]. Jackson MJ. The assessment of bioavailability of micronutrients: introduction. Eur J Clin Nutr 1997;51:S1-2.

[3]. Waschulewski IH, Sunde RA. Effect of dietary methionine on tissue selenium and glutathione peroxidase on tissue selenium and glutathione peroxidase activity given selenomethionine. $\mathrm{Br} \mathrm{J}$ Nutr 1988; 60:57-68. [PubMed: 3408706]

[4]. Fairweather-Tait SJ. Bioavailability of selenium. Eur J Clin Nutr 1997;51:S20-3. [PubMed: 9023475]

[5]. King JC. Effect of reproduction on the bioavailability of calcium, zinc and selenium. J Nutr 2001;131:1355S-8S. [PubMed: 11285354]

[6]. McGuire MK, Burgert SSL, Milner JA, et al. Selenium status of lactating women is affected by the form of selenium consumed. Am J Clin Nutr 1993;58:649-52. [PubMed: 8237870]

[7]. Michalke B, Schramel P. Selenium speciation in human milk with special respect to quality control. Biol Trace Elem Res 1997;59: 45-56. [PubMed: 9522046]

[8]. Ganther HE. Pathways of selenium metabolism including respiratory excretory products. J Am Coll Toxicol 1986;5:1-5.

[9]. Gronbaek H, Thorlacius-Ussing O. Selenium in the central nervous system of rats exposed to 75Se selenomethionine and sodium selenite. Biol Trace Elem Res 1992;35:119-27. [PubMed: 1280978]

[10]. Hill KE, Burk RF, Lane JM. Effect of selenium depletion and repletion on plasma glutathione and glutathione-dependent enzymes in the rat. J Nutr 1987;117:99-104. [PubMed: 3819879]

[11]. Burk RF, Hill KE, Awad JA, Morrow JD, Lyons PR. Liver and kidney necrosis in selenium deficient rats depleted of glutathione. Lab Invest 1995;72:723-30. [PubMed: 7783430]

[12]. Uthus EO, Yokoi K, Davis CD. Selenium deficiency in Fisher-344 rats decreases plasma and tissue homocysteine concentrations and alters plasma homocysteine and cysteine redox status. $\mathrm{J}$ Nutr 2002;132: 1122-8. [PubMed: 12042420]

[13]. Tapiero H, Tew KD, Gaté L, Machover D. Prevention of pathologies associated with oxidative stress and dietary intake deficiencies: folate deficiencies and requirements. Biomed Pharmacother 2001;55: 381-90. [PubMed: 11669501]

[14]. Ashfield-Watt PAL, Moat SJ, Doshi SN, McDowell IFW. Folate homocysteine, endothelial function and cardiovascular disease. What is the link? Biomed Pharmacother 2001;55:425-33. [PubMed: 11686575]

[15]. Chern C-L, Huang R-FS, Chen J-T, Cheng T-ZL. Folate deficiency induced oxidative stress and apoptosis are mediated via homocysteine-dependent overproduction of hydrogen peroxide and enhanced activation of NF-jB in human Hep G2 cells. Biomed Pharmacother 2001;55:434-42. [PubMed: 11686576]

[16]. Jakubowski H Protein N homocysteinylation: implications for atherosclerosis. Biomed Pharmacother 2001;55:443-7. [PubMed: 11686577]

[17]. Valera-Moreiras G Nutritional regulation of homocysteine: effects of drugs. Biomed Pharmacother 2001;55:448-53. [PubMed: 11686578]

[18]. Beck M, Shi Q, Morris V, Levander O. Rapid genomic evolution of a non-virulent Coxsackie virus B3 in selenium deficient mice results in selection of identical isolates. Nature Med 1995;1:433-41. [PubMed: 7585090]

[19]. Davis CD, Uthus EO. Dietary selenium and azadeoxycytidine treatment affect dimethylhydrazine-induced aberrant crypt formation in rat liver colon and DNA methylation in HT-29 cells. J Nutr 2002;132: 292-7. [PubMed: 11823593]

[20]. Ganapathy SN, Thimaya S. In: Watson RR, editor. Trace elements in human health and disease, vol. 3 Boca Raton, FL: CRC Press; 1985 p. 111-22.

[21]. Vanderpas JB, Contempre B, Duale NL, et al. Iodine and selenium deficiencies associated with cretinism in northern Zaïre. Am J Clin Nutr 1990;52:1087-93. [PubMed: 2239787]

[22]. Vanderpas JB, Contempre B, Duale NL, et al. Selenium deficiency mitigates hypothyroxinemia in iodine-deficient subjects. Am J Clin Nutr 1993;57:271S-5S. [PubMed: 8427203]

[23]. Cheng YY, Qian PC. The effect of selenium-fortified table salt in the prevention of Keshan disease on a population of 1.05 million. Biomed Environ Sci 1990;3:422-8. [PubMed: 2096847] 
[24]. Aro A, Kumpulainen J, Alfthan G, et al. Factors affecting the selenium intake of people in transbaikalian Russia. Biol Trace Element Res 1994;40:277-85.

[25]. Ferrans VJ. Pathologic anatomy of the dilated cardiomyopathies. Am J Cardiol 1989;64:9C-11C.

[26]. Arthur JR, Beckett GJ. Thyroid function: review. Br Med Bull 1999; 55:658-68. [PubMed: 10746354]

[27]. Allander E Kashin-Beck disease. An analysis of research and public health activities based on a bibliography 1849-1992. Scand J Rheumatol Suppl 1994;99:1-36. [PubMed: 7801051]

[28]. Yang C, Niu C, Bodo M, et al. Fulvic acid supplementation and selenium deficiency disturb the structural integrity of mouse skeletal tissue. An animal model to study the molecular defects of Kashin-Beck disease. Biochem J 1993;289:829-35. [PubMed: 8435081]

[29]. Peng A, Wang WH, Wang CX, et al. The role of humic substances in drinking water in KashinBeck disease in China. Environ Health Perspect 1999;107:293-6. [PubMed: 10090708]

[30]. Chasseur C, Suetens C, Nolard N, Begaux F, Haubruge E. Fungal contamination in barley and Kashin-Beck disease in Tibet. Lancet 1997;350:1074.

[31]. Burk RF, Hill KE. Regulation of selenoproteins. Annu Rev Nutr 1993;13:65-81. [PubMed: 8369160]

[32]. Behne D, Weiss-Nowak C, Kalklösch M, et al. Studies on the distribution and characteristics of new mammalian selenium-containing proteins. Analyst 1995;120:823-5. [PubMed: 7741234]

[33]. Tamura T, Stadtman TC. A new selenoprotein from human lung adenocarcinoma cells: purification, properties and thioredoxin reductase activity. Proc Natl Acad Sci USA 1996;93:1006-11. [PubMed: 8577704]

[34]. Gladyshev VN, Hatfield DL. Review: selenocysteine-containing proteins in mammals. J Biomed Sci 1999;6:151-60. [PubMed: 10343164]

[35]. Brigelius-Flohe R Review: tissue-specific functions of individual glutathione peroxidases. Free Radic Biol Med 1999;27:951-65. [PubMed: 10569628]

[36]. Rotruck JT, Pope AL, Ganther HE, et al. Selenium: biochemical role as a component of glutathione peroxidase. Science 1973;179:588-90. [PubMed: 4686466]

[37]. Chu F-F, Doroshow JS, Esworthy RS. Expression, characterization and tissue distribution of a new cellular Se-dependent glutathione peroxidase, GSHPX-GI. J Biol Chem 1993;268:2571-6. [PubMed: 8428933]

[38]. Takahashi K, Avissar N, Whithin J, Cohen H. Purification and characterization of human plasma glutathione peroxidase: a selenoglycoprotein distinct from the known cellular enzyme. Arch Biochem Biophys 1987;256:677-86. [PubMed: 3619451]

[39]. Ursini F, Maiorino M, Gregolin C. The selenoenzyme phospholipid hydroperoxide peroxidase. Biochim Biophys Acta 1985;839:62-70. [PubMed: 3978121]

[40]. Lei XG, Evenson JK, Thompson KM, Sunde RA. Glutathione peroxidase and phospholipid hydroperoxide glutathione peroxidase are differentially regulated in rats by dietary selenium. $\mathrm{J}$ Nutr 1995;125: 1438-46. [PubMed: 7782896]

[41]. Read R, Bellew T, Yang J-G, et al. Se and amino acid composition of selenoprotein P, the major selenoprotein in rat serum. J Biol Chem 1990;265:17899-905. [PubMed: 2211667]

[42]. Deagen JT, Butler JA, Zachara BA, Whanger PD. Determination of the distribution of Se between glutathione peroxidase, selenoprotein $\mathrm{P}$ and albumin in plasma. Anal Biochem 1993;208:176-84. [PubMed: 8434786]

[43]. Hill KE, Xia Y, Akesson B, et al. Selenoprotein P concentration in plasma as an index of selenium status in selenium deficient and selenium supplemented Chinese subjects. J Nutr 1996;126:138-45. [PubMed: 8558294]

[44]. Burk RF, Hill KE, Read R, et al. Response of rat selenoprotein P to selenium administration and fate of its selenium. Am J Physiol 1991; 261:E26-30. [PubMed: 1858872]

[45]. Hill KE, Lloyd RS, Burk RF. Conserved nucleotide sequences in the open reading frame and 3' untranslated region of selenoprotein P mRNA. Proc Natl Acad Sci USA 1993;90:537-41. [PubMed: 8421687]

[46]. Dreher I, Schmutzler C, Jakob F, Kohrle J. Expression of selenoproteins in various rat and human tissues and cell lines. J Trace Elem Med Biol 1997;11:83-91. [PubMed: 9285888] 
[47]. Yang X, Hill KE, Maguire MJ, Burk RF. Synthesis and secretion of selenoprotein P by cultured rat astrocytes. Biochim Biophys Acta 2000;1474:390-6. [PubMed: 10779692]

[48]. Koga M, Tanaka H, Yomogida K, et al. Expression of selenoprotein messenger ribonucleic acid in the rat testis. Biol Reprod 1998;58: 261-5. [PubMed: 9472950]

[49]. Mörk H, Al-Taie OH, Bähr K, et al. Inverse mRNA expression of the selenocysteine-containing proteins GI-GPX and SeP in colorectal adenomas compared with adjacent normal mucosa. Nutr Cancer 2000;37:108-16. [PubMed: 10965527]

[50]. Tanaka T, Kondo S, Iwasa Y, Hiai H, Toyokuni S. Expression of stress-response and cell proliferation genes in renal cell carcinoma induced by oxidative stress. Am J Pathol 2000;156:2149-57. [PubMed: 10854235]

[51]. Burk RF, Hill KE. Orphan selenoproteins. Bioassays 1999;21:231-7.

[52]. Hill KE, Lloyd RS, Yang J-G, Read R, Burk RF. The cDNA for rat selenoprotein P contains 10 TGA codons in the open reading frame. J Biol Chem 1991;266:10050-3. [PubMed: 2037562]

[53]. Yang J-G, Hill KE, Burk RF. Dietary Se intake controls rat plasma selenoprotein P concentration. J Nutr 1989;119:1010-2. [PubMed: 2754506]

[54]. Burk RF, Hill KE, Awad JA, Morrow JD, Kato T, Cockell KA, et al. Pathogenesis of diquatinduced liver necrosis in selenium-deficientrats: assessment of the roles of lipid peroxidation and selenoprotein P. Hepatology 1995;21:561-9. [PubMed: 7843731]

[55]. Burk RF, Early DS, Hill KE, Palmer IS, Boeglin ME. Plasma selenium in patients with cirrhosis. Hepatology 1998;27:794-8. [PubMed: 9500709]

[56]. Gu Q-P, Sun Y, Ream LW, Whanger PD. Selenoprotein W accumulates primarily in primate skeletal muscle, heart, brain and tongue. Mol Cell Biochem 2000;204:49-56. [PubMed: 10718624]

[57]. Yeh J-Y, Beilstein MA, Andrews JS, Whanger PD. Tissue distribution and influence of Se status on levels of Se-W. FASEB J 1995;9:392-6. [PubMed: 7896009]

[58]. Vendeland SC, Beilstein MA, Chen CL, et al. Purification and properties of Se-W from rat muscle. J Biol Chem 1993;268:17103-7. [PubMed: 8349599]

[59]. Vendeland SC, Beilstein MA, Yeh J-Y, Ream W, Whanger PD. Rat skeletal muscle Se-W: cDNA clone and mRNA modulation by dietary Se. Proc Natl Acad Sci USA 1995;92:8749-53. [PubMed: 7568010]

[60]. Kryukov GV, Kryukov VM, Gladyshev VN. New mammalian selenocysteine-containing proteins identified with an algorithm that searches for selenocysteine insertion sequence elements. J Biol Chem 1999;274:33888-97. [PubMed: 10567350]

[61]. Björnstedt M, Kumar S, Björkhem L, Spyrou G, Holmgren A. Selenium and the thioredoxin and glutaredoxin systems. Biomed Environ Sci 1997;10:271-9. [PubMed: 9315320]

[62]. Gasdaska JR, Kirkpatrick DL, Montfort W, Kuperus M, Hill SR, Bergrren M, et al. Biochem Pharmacol 1996;52:1741-7. [PubMed: 8986137]

[63]. Sahaf B, Söderberg A, Spyrou G, Barral AM, Pekkari K, Holmgren A, et al. Thioredoxin expression and localization in human cell lines: detection of full-length and truncated species. Exp Cell Res 1997;236:181-92. [PubMed: 9344598]

[64]. Baker A, Payne CM, Briehl MM, Powis G. Thioredoxine, a gene found overexpressed in human cancer, inhibits apoptosis in vitro and in vivo. Cancer Res 1997;57:5162-7. [PubMed: 9371519]

[65]. Arner ES, Holmgren A. Physiological functions of thioredoxin and thioredoxin reductase. Eur J Biochem 2000;267:6102-9. [PubMed: 11012661]

[66]. Hill KE, McCollum GW, Boeglin ME, Burk RF. Thioredoxin reductase activity is decreased by selenium deficiency. Biochem Biophys Res Commun 1997;234:293-5. [PubMed: 9177261]

[67]. Powis G, Gasdaska JR, Gasdaska PY, et al. Selenium and the thioredoxin redox system: effects on cell growth and death. Oncol Res 1997;9:303-12. [PubMed: 9406236]

[68]. Gallegos A, Berggren M, Gasdaska JR, Powis G. Mechanisms of the regulation of thioredoxin reductase activity in cancer cells by the chemopreventive agent selenium. Cancer Res 1997;57:4965-70. [PubMed: 9354464] 
[69]. Rozell B, Hansson HA, Luthman M, Holmgren A. Immunohistochemical localization of thioredoxin and thioredoxin reductase in adult rats. Eur J Cell Biol 1985;38:79-86. [PubMed: 3896810]

[70]. Lee SR, Kim JR, Kwon KS, Yoon HW, Levine RL, Ginsburg A, et al. Molecular cloning and characterization of a mitochondrial selenocysteine-containing thioredoxin reductase from rat liver. J Biol Chem 1999;274:4722-34. [PubMed: 9988709]

[71]. Köhrle J Thyroid hormone deiodination in target tissues - a regulatory role of the trace element selenium? Exp Clin Endocrinol 1994; 102:63-89. [PubMed: 8056056]

[72]. Clugston GA, Hetzel BS. Iodine. 8th ed. In: Shils ME, Olson JA, Shike M, editors. Modern nutrition in health and disease Philadelphia, PA: Lea \& Febiger; 1994 p. 252-63.

[73]. Contempré B, Dumont JE, Denef J-F, Many M-C. Effects of selenium deficiency on thyroid necrosis, fibrosis and proliferation: a possible role in myxoedematous cretinism. $\mathrm{J}$ Eur Endocrinol 1995;133: 99-109.

[74]. Hotz CS, Fitzpatrick DW, Trick KD, L’Abbé MR. Dietary iodine and selenium interact to affect thyroid hormone metabolism of rats. J Nutr 1997;127:1214-8. [PubMed: 9187638]

[75]. Ip C, Ganther H. Activity of methylated forms of selenium in cancer prevention. Cancer Res 1996;50:1206-11.

[76]. Ip C Lessons from basic research in selenium and cancer prevention. J Nutr 1998;128:1845-54. [PubMed: 9808633]

[77]. Ganther HE. Selenium metabolism, selenoproteins and mechanisms of cancer prevention: complexities with thioredoxin reductase. Carcinogenesis 1999;20:1657-66. [PubMed: 10469608]

[78]. Combs GF, Jr, Gray WP. Chemopreventive agents: selenium. Pharma-col Ther 1998;79:179-92.

[79]. Combs GF, Jr, Clark LC. Nutritional oncology In: Heber D, Black-burn GL, Go VLW, editors. New York: Academic Press Inc; 1999 p. 215.

[80]. Combs GF, Jr. Selenium and cancer. In: Garewal HS, editor. Antioxidants and disease prevention New York, NY: CRC Press; 1997 p. 97-113.

[81]. Spyrou G, Björnstedt M, Skog S, Holmgren A. Selenite and selenate inhibit human lymphocyte growth via different mechanisms. Cancer Res 1996;56:4407-12. [PubMed: 8813134]

[82]. Helzlsouer KJ, Alberg AJ, Norkus EP, Morris JS, Hoffman SC, Com-stock GW. Prospective study of serum micronutrients and ovarian cancer. J Natl Cancer Inst 1996;88:32-7. [PubMed: 8847723]

[83]. Nayini J, el-Bayoumy K, Sugie S, Cohen LA, Reddy BS. Chemoprevention of experimental mammary carcinogenesis by the synthetic organoselenium compound, benzylselenocyanate, in rats. Carcinogenesis 1989;10:509-12. [PubMed: 2538274]

[84]. Willett WC, Polk BF, Morris JS, Stampfer MJ, Pressel S, Rosner B, et al. Prediagnostic serum selenium and risk of cancer. Lancet 1983;2:130-4. [PubMed: 6134981]

[85]. van den Brandt PA, Goldbohm RA, van't Veer P, Bode P, Dorant E, Hermus RJ, et al. A prospective cohort study on toenail selenium levels and risk of gastrointestinal cancer. J Natl Cancer Inst 1993;85: 224-9. [PubMed: 8423627]

[86]. Nomura AM, Lee J, Stemmermann GN, Combs GF, Jr. Serum selenium and subsequent risk of prostate cancer. Cancer Epidemiol Biomarkers Prev 2000;9:883-7. [PubMed: 11008904]

[87]. Philipov P, Tzatchev K. Selenium concentrations in serum of patients with cerebral and extracerebral tumors. Zentralbl Neurochir 1988;49: 344-7. [PubMed: 3252652]

[88]. Jaskiewicz K, Marasas WF, Rossouw JE, Van Niekerk FE, Heine Tech EW. Selenium and other mineral elements in populations at risk for esophageal cancer. Cancer 1988;62:2635-9. [PubMed: 3191467]

[89]. Miyamoto H, Araya Y, Ito M, Isobe H, Dosaka H, Shimizu T, et al. Serum selenium and vitamin E concentrations in families of lung cancer patients. Cancer 1987;60:1159-62. [PubMed: 3038299]

[90]. Knekt P, Aromaa A, Maatela J, Alfthan G, Aaran RK, Hakama M, et al. Serum selenium and subsequent risk of cancer among Finnish men and women. J Natl Cancer Inst 1990;82:864-8. [PubMed: 2332904] 
[91]. Westin T, Ahlbom E, Johansson E, Sandstrom B, Karlberg I, Edstrom S. Circulating levels of selenium and zinc in relation to nutritional status in patients with head and neck cancer. Arch Oto-laryngol Head Neck Surg 1989;115:1079-82.

[92]. Helzlsouer KJ, Comstock GW, Morris JS. Selenium, lycopene, alpha-tocopherol, beta-carotene, retinol, and subsequent bladder cancer. Cancer Res 1989;49:6144-8. [PubMed: 2790827]

[93]. Burney PG, Comstock GW, Morris JS. Serologic precursors of cancer: serum micronutrients and the subsequent risk of pancreatic cancer. Am J Clin Nutr 1989;49:895-900. [PubMed: 2718925]

[94]. Glattre E, Thomassen Y, Thoresen SO, Haldorsen T, Lund-Larsen PG, Theodorsen L, et al. Prediagnostic serum selenium in a case-control study of thyroid cancer. Int J Epidemiol 1989;18:45-9. [PubMed: 2722382]

[95]. Caygill CP, Lavery K, Judd PA, Hill MJ, Diplock AT. Serum selenium and gastric cancer in two regions of Norfolk. Food Addit Contam 1989;6:359-63. [PubMed: 2721785]

[96]. Knekt P, Aromaa A, Maatela J, Alfthan G, Aaran RK, Teppo L, et al. Serum vitamin E, serum selenium and the risk of gastrointestinal cancer. Int J Cancer 1988;42:846-50. [PubMed: 3192329]

[97]. Reinhold U, Biltz H, Bayer W, Schmidt KH. Serum selenium levels in patients with malignant melanoma. Acta Derm Venereol 1989;69: 132-6. [PubMed: 2564230]

[98]. Yoshizawa K, Willett WC, Morris SJ, Stampfer MJ, Spiegelman D, Rimm EB, et al. Study of prediagnostic selenium level in toenails and the risk of advanced prostate cancer. J Natl Cancer Inst 1998;90: 1219-24. [PubMed: 9719083]

[99]. Clark LC, Hixson LJ, Combs GF, Jr, Reid ME, Turnbull BW, Sampliner RE. Plasma selenium concentration predicts the prevalence of colorectal adenomatous polyps. Cancer Epidemiol Biomarkers Prev 1993;2:41-6. [PubMed: 8420611]

[100]. Burke KE, Combs GF, Gross EG, et al. The effects of topical and oral L-selenomethionine on pigmentation and skin cancer induced by ultraviolet irradiation. Nutr Cancer 1992;17:123-37. [PubMed: 1584707]

[101]. Pence BC, Delver E, Dunn DM. Effects of dietary selenium on UVB-induced skin carcinogenesis and epidermal antioxidant status. J Invest Dermatol 1994;102:759-61. [PubMed: 8176260]

[102]. Diamond AM, Dale P, Murray JL, Grdina DJ. The inhibition of radiation-induced mutagenesis by the combined effects of selenium and the aminothiol WR-1065. Mutat Res 1996;356:147-54. [PubMed: 8841479]

[103]. Perchellet JP, Abney NL, Thomas RM, Guislain YL, Perchellet EM. Effects of combined treatments with selenium, glutathione, and vitamin $\mathrm{E}$ on glutathione peroxidase activity, ornithine decarboxylase induction, and complete and multistage carcinogenesis in mouse skin. Cancer Res 1987;47:477-85. [PubMed: 3098411]

[104]. Shimazu F, Tappei AL. Selenoamino acids decrease radiation damage to amino acids and proteins. Science (Washington, DC) 1964;143: 369-71.

[105]. Willett WC, Stampfer MJ. Selenium and cancer: whether selenium protects against cancer is still unknown. Br Med J 1988;297:573-9. [PubMed: 3139218]

[106]. Clark LC, Combs GF, Turnbull BW, et al. Effects of selenium supplementation for cancer prevention in patients with carcinoma of the skin. J Am Med Assoc 1996;276:1957-87.

[107]. Holden J, Gebhardt R, Davis C, Lurie D. A nationwide study of the selenium content and variability in white bread. J Food Comp Anal 1991;4:183-95.

[108]. Finley J, Matthys L, Shuler T, Korynta E. Selenium content of foods purchased in North Dakota. Nutr Res 1996;16:723-8.

[109]. Wu L, Lanfear J, Harrison PR. The selenium metabolite selenodiglutathione induces cell death by a mechanism distinct from H2O2 toxicity. Carcinogenesis 1995;16:1579-84. [PubMed: 7614692]

[110]. Bjornstedt M, Kumar S, Holmgren A. Selenodiglutathione is a highly efficient oxidant of reduced thioredoxin and a substrate for mammalian thioredoxin reductase. J Biol Chem 1992;267:8030-4. [PubMed: 1569062] 
[111]. Lanfear J, Fleming J, Wu L, Webster G, Harrison PR. The selenium metabolite selenodiglutathione induces p53 and apoptosis: relevance to the chemopreventive effects of selenium? Carcinogenesis 1994;15: 1387-92. [PubMed: 8033315]

[112]. Feng Y, Finley J, Davis C, et al. Dietary selenium reduces the formation of aberrant crypts in rats administered 3,2-dimethyl-4-aminobiphenyl. Toxicol Appl Pharmacol 1999;157:36-42. [PubMed: 10329505]

[113]. Vadhanavikit S, Ip C, Ganther H. Metabolites of sodium selenite and methylated selenium compounds administered at cancer chemoprevention levels in the rat. Xenobiotica 1993;23:73145. [PubMed: 8237056]

[114]. Ganther HE, Lawrence JR. Chemical transformations of selenium in living organisms. Improved forms of selenium for cancer prevention. Tetrahedron 1997;53:12299-310.

[115]. Jiang C, Jiang W, Ip C, Ganther H, Lu J. Selenium-induced inhibition of angiogenesis in mammary cancer at chemopreventive levels of intake. Mol Carcinogen 1999;26:213-25.

[116]. Ip C, Thompson HJ, Zhu Z, Ganther HE. In vitro and in vivo studies of methylselenic acid: evidence that a monomethylated selenium metabolite is critical for cancer prevention. Cancer Res 2000;60: 2882-6. [PubMed: 10850432]

[117]. Cai X-J, Block E, Uden Pc, et al. Allium chemistry: identification of selenoamino acids in ordinary and selenium enriched garlic, onion, and broccoli using gas chromatography with atomic emission detection. J Agric Food Chem 1995;43:1754-7.

[118]. Ip C, Lisk DJ. Characterization of tissue selenium profiles and anti-carcinogenic responses in rats fed natural sources of selenium-rich products. Carcinogenesis 1994;15:573-6. [PubMed: 8149465]

[119]. Davis CD, Zeng H, Finley JW. Selenium enriched broccoli decreases intestinal tumorigenesis in multiple intestinal neoplasia mice. J Nutr 2002;132:307-9. [PubMed: 11823596]

[120]. Finley JW, Davis CD, Feng Y. Selenium from high selenium broccoli protects rats from colon cancer. J Nutr 2000;130:2384-9. [PubMed: 10958840]

[121]. Ip C, Thompson HJ, Ganther HE. Selenium modulation of cell proliferation and cell cycle biomarkers in normal and premalignant cells of the rat mammary gland. Cancer Epidemiol Biomarkers Prev 2000;9: 49-54. [PubMed: 10667463]

[122]. Reddy BS, Rivenson A, El Bayoumi K, Upadhyaya P, Pittman B, Rao CV. Chemoprevention of colon cancer by organoselenium compounds and impact of high-or low-fat diet. J Natl Cancer Inst 1997; 89:506-12. [PubMed: 9086007]

[123]. El-Bayoumi K, Chae Y-H, Upadhyaya P, et al. Selenium in chemoprevention of carcinogenesis II. Inhibition of 7,12-dimethyl-benz(a) anthracene induced tumors and DNA adduct formation in the mammary glands of female Sprague-Dawley rats by the synthetic organoselenium compound 1,4-phenylenebis (methylene) selenocyanate. Cancer Res 1992;52:2402-7. [PubMed: 1568209]

[124]. Ip C, El-Bayoumi K, Upadhyaya P, et al. Comparative effect of inorganic and organic selenocyanate derivatives in mammary cancer chemoprevention. Carcinogenesis 1994;15:18792. [PubMed: 8313507]

[125]. Thompson HJ, Wilson A, Lu J, et al. Comparison of the effects of an organic and an inorganic form of selenium on a mammary carcinoma cell line. Carcinogenesis 1994;15:183-6. [PubMed: 8313506]

[126]. Tillotson JK, Upadhyaya P, Ronai Z. Inhibition of thymidine kinase in cultured mammary tumor cells by the chemopreventive organoselenium compound 1,4phenylenebis(methylene)selenocyanate. Carcinogenesis 1994;15:597-601.

[127]. Favier A, Sappey C, Leclerc P, Faure P, Micoud M. Antioxidant status and lipid peroxidation in patients infected with HIV. Chem Biol Interact 1994;91:165-80. [PubMed: 8194133]

[128]. Dobmeyer TS, Findhammer S, Dobmeyer JM, Klein SA, Raffel B, Hoelzer D, et al. Ex vivo induction of apoptosis in lymphocytes is mediated by oxidative stress: role for lymphocyte loss in HIV infection. Free Radic Biol Med 1997;22:775-85. [PubMed: 9119245]

[129]. Pace GW, Leaf CD. The role of oxidative stress in HIV disease. Free Radic Biol Med 1995;19:523-8. [PubMed: 7590404]

[130]. Mallery SR, Bailer RT, Hohl CM, Ng-Bautista CL, Ness GM, Livingston BE, et al. Cultured AIDS-related Kaposi's sarcoma (AIDS-KS) cells demonstrate impaired bioenergetic adaptation 
to oxidant challenge: implication for oxidant stress in AIDS-KS pathogenesis. J Cell Biochem 1995;59:317-28. [PubMed: 8567750]

[131]. Dewhurst S, Gelbard HA, Fine SM. Neuropathogenesis of AIDS. Mol Med Today 1996;2:1623. [PubMed: 8796847]

[132]. Muller F, Svardal AM, Aukrust P, Berge RK, Ueland PM, Froland SS. Elevated plasma concentration of reduced homocysteine in patients with human immunodeficiency virus infection. Am J Clin Nutr 1996; 63:242-8. [PubMed: 8561066]

[133]. Aukrust P, Svardal AM, Muller F, Lunden B, Berge RK, Ueland PM, et al. Increased levels of oxidized glutathione in $\mathrm{CD} 4+$ lymphocytes associated with disturbed intracellular redox balance in human immunodeficiency virus type 1 infection. Blood 1995;86: 258-67. [PubMed: 7795231]

[134]. Baum MK, Shor-Posner G. Micronutrient status in relationship to mortality in HIV-1 disease. Nutr Rev 1998;56:S135-9. [PubMed: 9481135]

[135]. Tang AM, Graham NM, Semba RD, Saah AJ. Association between serum vitamin A and E levels and HIV-1 disease progression. AIDS 1997;11:613-20. [PubMed: 9108943]

[136]. Look MP, Rockstroh JK, Rao GS, Kreuzer KA, Spengler U, Sauer-bruch T. Serum selenium versus lymphocyte subsets and markers of disease progression and inflammatory response in human immunodeficiency virus-1 infection. Biol Trace Elem Res 1997;56:31-41. [PubMed: 9152510]

[137]. Moutet M, d'Alessio P, Malette P, Devaux V, Chaudiere J. Glutathione peroxidase mimics prevent TNF-alpha- and neutrophil-induced endothelial alterations. Free Radic Biol Med 1998;25:270-81. [PubMed: 9680172]

[138]. Roy M, Kiremidjian-Schumacher L, Wishe HI, Cohen MW, Stotzky G. Selenium supplementation enhances the expression of interleukin 2 receptor subunits and internalization of interleukin 2. Proc Soc Exp Biol Med 1993;202:295-301. [PubMed: 8437984]

[139]. Haslett PA. Anticytokine approaches to the treatment of anorexia and cachexia. Semin Oncol 1998;25:53-7.

[140]. Hori K, Hatfield D, Maldarelli F, Lee BJ, Clouse KA. Selenium supplementation suppresses tumor necrosis factor alpha-induced human immunodeficiency virus type 1 replication in vitro. AIDS Res Hum Retroviruses 1997;13:1325-32. [PubMed: 9339849]

[141]. Delmas-Beauvieux MC, Peuchant E, Couchouron A, Constans J, Sergeant C, Simonoff M, et al. The enzymatic antioxidant system in blood and glutathione status in human immunodeficiency virus (HIV)-infected patients: effects of supplementation with selenium or beta-carotene. Am J Clin Nutr 1996;64:101-7. [PubMed: 8669404]

[142]. Cirelli A, Ciardi M, de Simone C, Sorice F, Giordano R, Ciaralli L, et al. Serum selenium concentration and disease progress in patients with HIV infection. Clin Biochem 1991;24:211-4. [PubMed: 2040094]

[143]. Finkel T, Holbrook NJ. Oxidants, oxidative stress and the biology of ageing. Nature 2000;408:239-47. [PubMed: 11089981]

[144]. Lesourd BM. Nutrition and immunity in the elderly: modification of immune responses with nutritional treatments. Am J Clin Nutr 1997; 66:478S-84S. [PubMed: 9250135]

[145]. Mazari L, Lesourd BM. Nutritional influences on immune response in healthy aged persons. Mech Ageing Dev 1998;104:25-40. [PubMed: 9751430]

[146]. Albright JW, Albright JF. Impaired natural killer cell function as a consequence of aging. Exp Gerontol 1998;33:13-25. [PubMed: 9467713]

[147]. Olivieri O, Girelli D, Azzini M, Stanzial AM, Russo C, Ferroni M, et al. Low selenium status in the elderly influences thyroid hormones. Clin Sci (Lond) 1995;89:637-42. [PubMed: 8549083]

[148]. Olivieri O, Girelli D, Stanzial AM, Rossi L, Bassi A, Corrocher R. Selenium, zinc, and thyroid hormones in healthy subjects: low T3/T4 ratio in the elderly is related to impaired selenium status. Biol Trace Elem Res 1996;51:31-41. [PubMed: 8834378]

[149]. Ruz M, Codoceo J, Galgani J, Munoz L, Gras N, Muzzo S, et al. Single and multiple seleniumzinc-iodine deficiencies affect rat thyroid metabolism and ultrastructure. J Nutr 1999;129:17480. [PubMed: 9915896] 
[150]. Savarino L, Granchi D, Ciapetti G, Cenni E, Ravaglia G, Forti P, et al. Serum concentrations of zinc and selenium in elderly people: results in healthy nonagenarians/centenarians. Exp Gerontol 2001;36: 327-39. [PubMed: 11226746]

[151]. Kauf E, Dawczynski H, Jahreis G, Janitzky E, Winnefeld K. Sodium selenite therapy and thyroid-hormone status in cystic fibrosis and congenital hypothyroidism. Biol Trace Elem Res 1994;40:247-53. [PubMed: 7517162]

[152]. Serra V, Grune T, Sitte N, Saretzki G, von Zglinicki T. Telomere length as a marker of oxidative stress in primary human fibroblast cultures. Ann NY Acad Sci 2000;908:327-30. [PubMed: 10911978] 


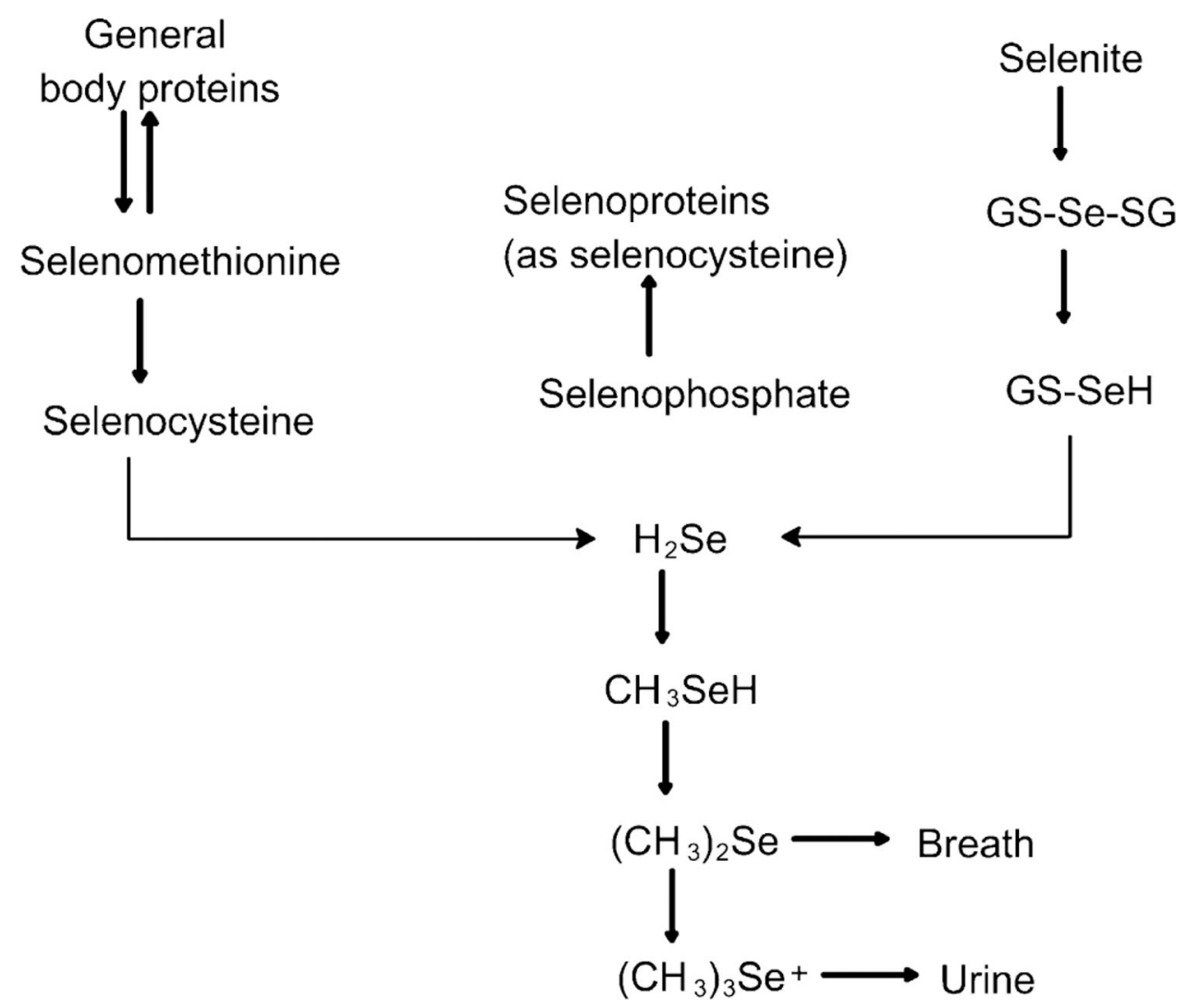

Fig. 1.

Selenium incorporation in plants and animals. Cereals, grains and vegetables convert selenium mainly into Se-Met and incorporate it into protein in place of methionine (Met). Se-Met can account for $>50 \%$ of the total Se content of the plant whereas, selenocystine (SeCys), methyl-Se-Cys and gamma-glutamyl-Se-methyl-Cys are not significantly incorporated into plant protein. Higher animals are unable to synthesize Se-Met and only Se-Cys was detected in rats supplemented with Se as selenite. In yeast (Saccharomyces cerevisae), most of the total Se (>90\%) is in the form of L-Se-Met. 


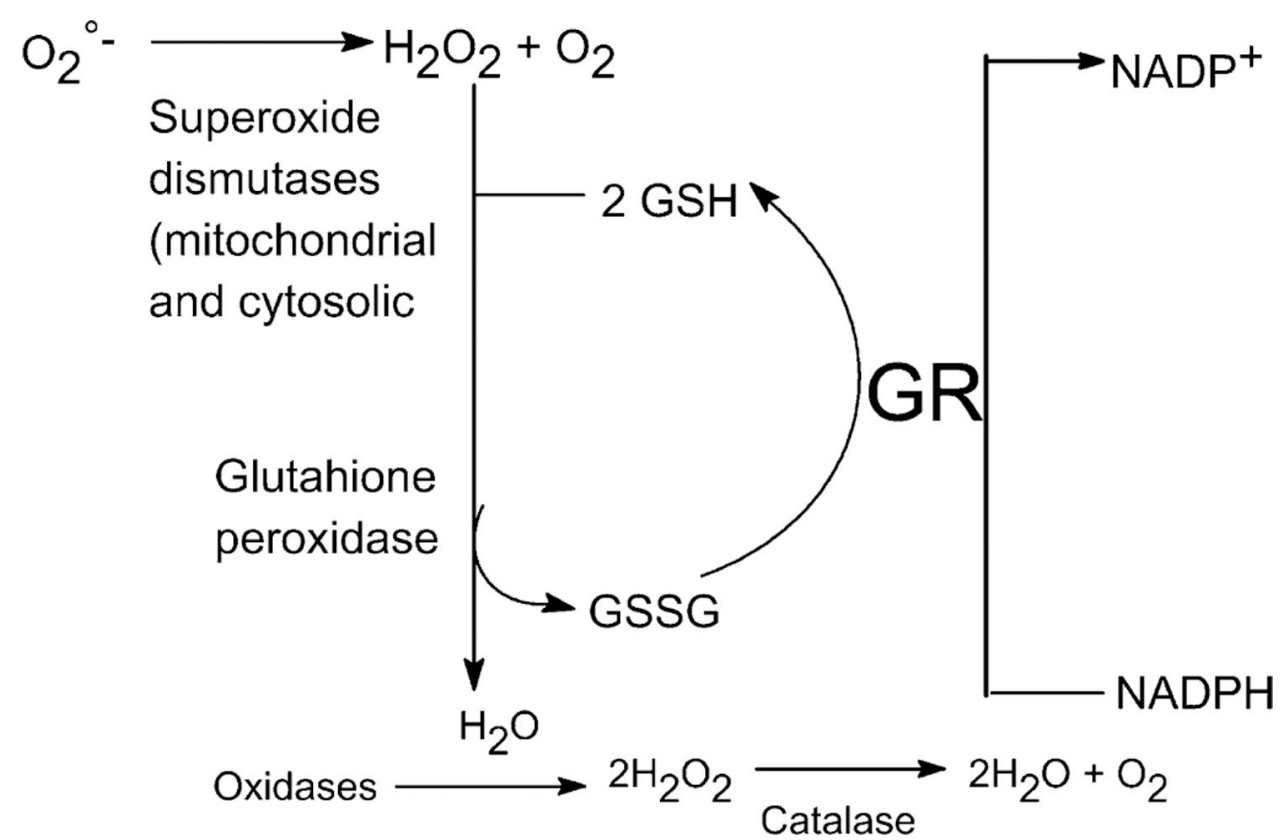

Fig. 2.

The role of catalase and glutathione peroxidase in removing hydrogen peroxide in human tissue. 

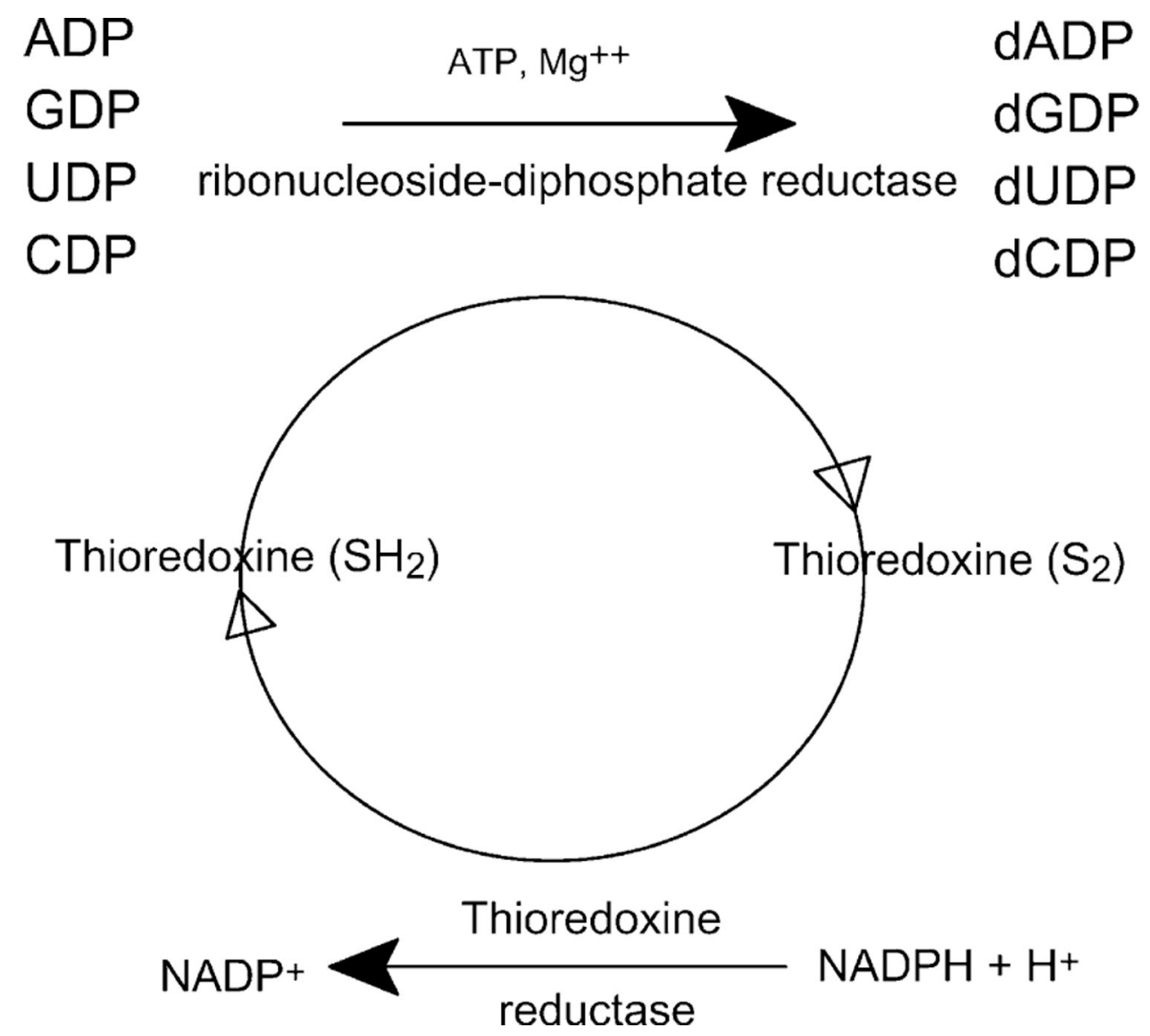

Fig. 3.

Role of thioredoxin in the reduction of ribonucleosides-5'-diphosphates to deoxyribonucleosides-5' -diphosphate. 


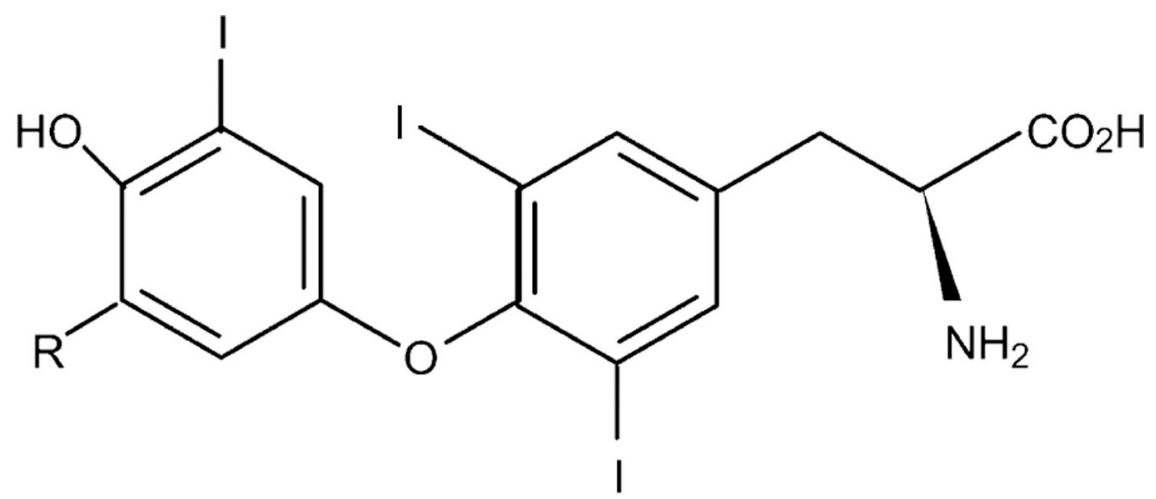

$R=I:$ Thyroxine $=$ Levothyroxine $\left(T_{4}\right)$ $\mathrm{R}=\mathrm{H}:$ Tri-iodothyronine $\left(\mathrm{T}_{3}\right)$

Fig. 4.

Formulae of thyroxine and triiodothyronine. 


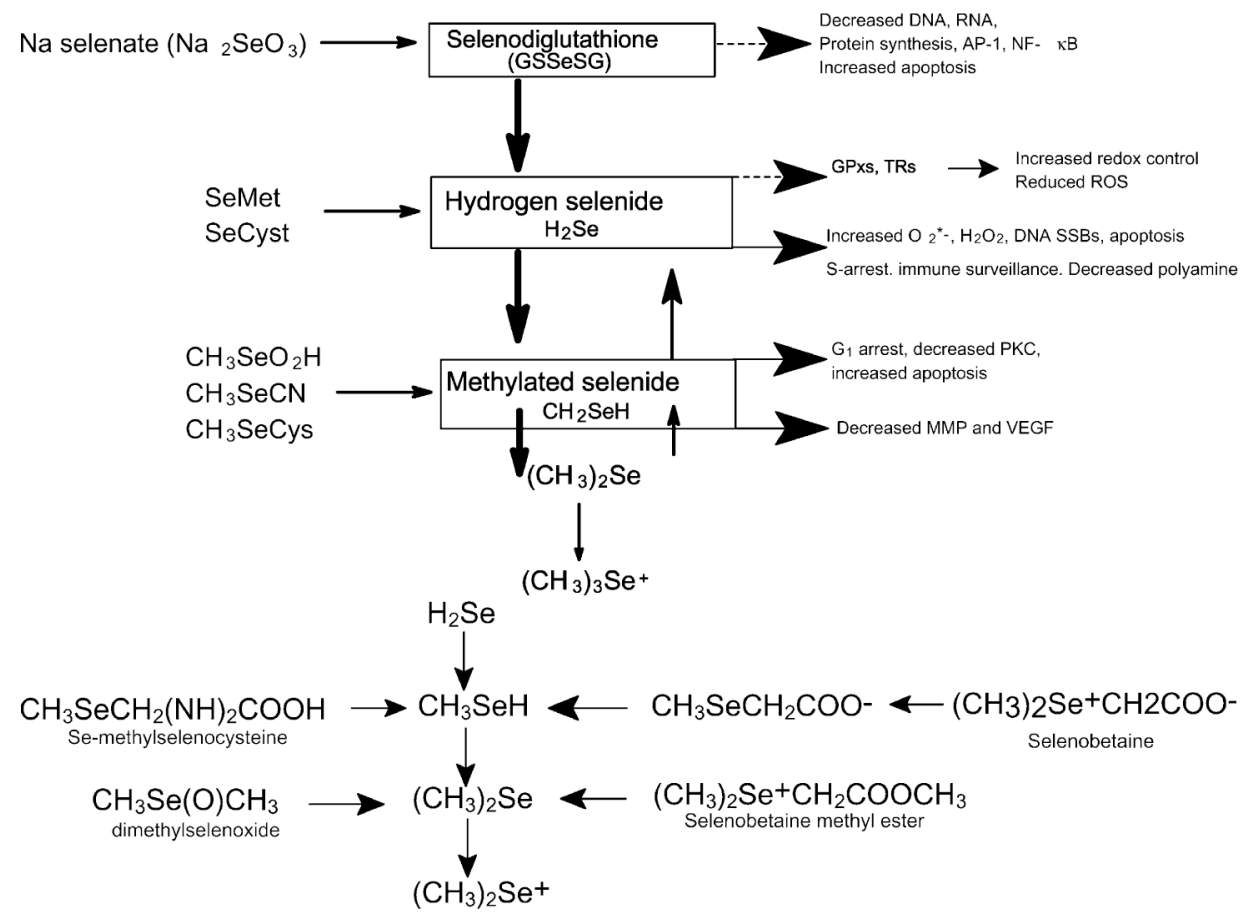

Fig. 5.

(a) Selenium compounds in cancer prevention. (b) Methylated selenium compounds. Methylated selenium compounds have been shown to modify various biological processes including suppression of angiogenesis and cancer prevention. Se ingested as Se-Met may follow the transsulfuration pathway, converted to Se-Cys and then cleaved to produce selenide. In contrast, Se-methyl selenocysteine (SeMSC) may be converted to methyl selenol by cleavage of the Se-methyl group. The chemical form of Se found in broccoli is similar to that found in Se garlic and the inhibition of carcinogenesis seems to be a consequence of the uniqueness of Se in those plants and not a consequence of the total intake of Se, garlic or broccoli. 
<smiles>COc1ccc(S)cc1</smiles><smiles>N#[As]c1ccc([AsH2])cc1</smiles>
p-methoxybenzeneselenol<smiles>c1ccc([Se-](c2ccccc2)(c2ccccc2)c2ccccc2)cc1</smiles>

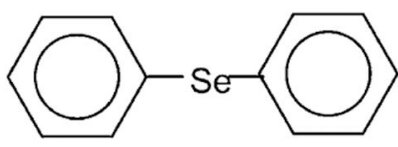

Diphenylselenide<smiles>CC(C)(C)CSc1ccc(Cc2ccc(C#N)cc2)cc1</smiles>

1,4-phenylene-bis (methylene) selenocyanate<smiles>COc1ccccc1</smiles>

Methylphenylselenide

Triphenylselenonium

Fig. 6.

Synthetic organoselenium compounds. Synthetic organoselenium compounds have been designed to achieve greater chemoprevention efficacy and to reduce toxic side effects. The chemopreventive activity of $\mathrm{p}$-XSC is associated to the decreased level of prostaglandin $\mathrm{E}_{2}$ $\left(\mathrm{PGE}_{2}\right)$ and the enhancement of GSH-Px activity in rat colon. 


\section{Table 1}

Disease states possibly associated with selenium deficiency

\begin{tabular}{l} 
Keshan disease (cardiomyopathy of children and young women) \\
Cardiomyopathy in patients on total parenteral nutrition \\
Muscle weakness and pain \\
Nail changes \\
T and B cell dysfunction \\
Cancer (uncertain association) \\
Coronary artery disease (uncertain association) \\
\hline
\end{tabular}

